\title{
ANALISIS KESALAHAN SISWA DALAM MENYELESAIKAN PERMASALAHAN MATEMATIKA MENURUT TEORI POLYA DITINJAU BERDASARKAN KECEMASAN MATEMATIKA
}

\author{
Rizal Fahmi Himawan \\ Program Studi Pendidikan Matematika, FMIPA, Universitas Negeri Surabaya \\ e-mail: rizalhimawan16030174042@mhs.unesa.ac.id \\ Raden Sulaiman \\ Program Studi Pendidikan Matematika, FMIPA, Universitas Negeri Surabaya \\ e-mail: radensulaiman@unesa.ac.id
}

\begin{abstract}
Abstrak
Kecemasan matematika adalah rasa panik, tidak berdaya, kekakuan, lumpuh, dan gangguan mental yang muncul dalam diri seseorang ketika mereka diminta untuk menyelesaikan suatu permasalahan matematika secara menyeluruh pada aktivitas sehari-hari atau dalam situasi akademik. Kecemasan matematika dapat menghasilkan efek negatif kepada kemampuan belajar, kemampuan menerapkan, dan kemampuan memecahkan masalah. Penggunaan permasalahan matematika yang tidak umum, dapat mendorong perkembangan kemampuan berpikir kritis, kreatif dan higher order thinking skills dari siswa tersebut. Tujuan penelitian ini yaitu mendeskripsikan mengenai jenis-jenis kesalahan siswa kelas VIII SMP dalam menyelesaikan masalah matematika pada materi phytagoras berdasarkan teori Polya dengan tingkat kecemasan matematika tinggi dan rendah. Penelitian ini termasuk penelitian deskriptif dengan pendekatan kualitatif. Sumber data yaitu siswa 5 SMP kelas VIII semester genap. Terdapat 3 instrumen dalam penelitian ini yaitu: Angket kecemasan matematika, Tes pemecahan masalah matematika, dan Pedoman wawancara. Angket kecemasan matematika yang digunakan yaitu angket kecemasan yang diadaptasi dari angket yang dikembangkan oleh Mahmood dan Khatoon yang diperoleh dari adaptasi angket Mathematics Anxiety Scale. Tes penyelesaian masalah matematika digunakan untuk mengetahui letak kesalahan siswa dalam proses pemecahan masalah matematika. Wawancara digunakan untuk mengetahui alasan dan faktor penyebab siswa melakukan kesalahan dalam proses pemecahan masalah matematika. Hasil penelitian menunjukkan bahwa: 1. Siswa SMP Kelas VIII dengan tingkat kecemasan matematika tinggi melakukan kesalahan kategori kesalahan prosedural dalam tahap membuat rencana, menjalankan rencana dan memeriksa kembali. 2. Siswa SMP Kelas VIII dengan tingkat kecemasan matematika rendah melakukan kesalahan kategori kesalahan konseptual dalam tahap memeriksa kembali.
\end{abstract}

Kata Kunci: Kecemasan Matematika, Masalah Matematika, Pemecahan Masalah Matematika Teori Polya.

\begin{abstract}
Mathematical anxiety is a feeling of panic, helplessness, stiffness, paralysis, and mental disorders that arise in a person when they are asked to solve a mathematical problem thoroughly in everyday life or in academic situations. Mathematical anxiety can have a negative effect on learning ability, application skills, and problem solving abilities. The use of uncommon mathematical problems can encourage the development of critical, creative thinking skills and higher order thinking skills from these students. The purpose of this study was to describe the types of errors made by VIII grade Junior High School student in solving a problem with Pythagorean material based on Polya's theory with a high and a low level of mathematical anxiety. This research is a descriptive study using a qualitative approach. Sources of data in this study were 5 VIII grade Junior High School student even semester. There are 3 instruments in this research, namely: mathematics anxiety scale questionnaire, mathematics problem solving test, and interview guide. The mathematics anxiety scale used was an anxiety scale that was adapted from a scale developed by Mahmood and Khatoon which was obtained from an adaptation of the Mathematics Anxiety Scale questionnaire. Math problem solving tests are used to find out where students' mistakes are in the process of solving mathematical problems. Interviews are used to find out the reasons and factors that cause students to make mistakes in the process of solving mathematical problems. The results showed that: 1. Grade VIII junior high school students with a high level of mathematics anxiety made mistakes in procedural mistake category in the stages of making plans stage, executing plans stage, and re-checking stage. 2. Grade VIII junior high school students with low mathematical anxiety level made mistakes in conceptual mistake category in the re-checking stage.
\end{abstract}


Keywords: Mathematical Anxiety, Mathematical Problems, Polya's Theory Mathematical Problem Solving.

\section{PENDAHULUAN}

Di Indonesia terdapat beberapa cabang ilmu yang diajarkan kepada warga negara Indonesia. Salah satu dari cabang ilmu tersebut yaitu matematika . Carl Friedrich Gauss berpendapat bahwa matematika adalah ratu dari ilmu. Berbagai cabang ilmu pengetahuan seperti kesehatan, teknik, ekonomi, seni, desain, sosial dan cabang-cabang ilmu lainnya menggunakan konsep-konsep matematika. Matematika dapat memengaruhi perkembangan ilmu lainnya. Semakin cepat perkembangan ilmu matematika, maka semakin cepat perkembangan ilmu lainnya. Sehingga, Matematika secara langsung ataupun tidak langsung memiliki peranan penting dalam setiap sisi kehidupan manusia.

Pendidikan matematika di Indonesia dapat dimulai dari masa pra-sekolah, dimana individu akan belajar tentang konsep bilangan dan bentuk dasar geometri. Pembelajaran matematika di Indonesia selalu ada di tiap jenjang pendidikan, mulai dari sekolah dasar, sekolah menengah pertama, sekolah menengah akhir hingga perguruan tinggi. Hal ini menunjukkan bahwa matematika di Indonesia merupakan cabang pendidikan yang relatif penting di Indonesia.

Menurut Singgih D. Gunarsa (2001) kecemasan adalah pergantian suasana hati, pergantian pada diri sendiri yang mencuat dari dalam tanpa adanya rangsangan dari luar. Menurut Luttenberger, Wimmer, Paechter (2018) berdasarkan studi di tahun 2006 kecemasan merupakan salah satu gangguan mental yang paling banyak dialami manusia di bumi. Diperkirakan terdapat $17 \%$ warga dari berbagai negara memiliki kecemasan baik itu kecemasan secara umum, obsessive-compulsive disorder, kepanikan, fobia, kecemasan sosial, dan post-traumatic stress disorder. Perempuan lebih beresiko mengalami kecemasan dibandingkan dengan laki-laki. Kecemasan tidak hanya dialami oleh orang dewasa, anak-anak dan remaja juga mengalami kecemasan, dengan persentase kecemasan paling tinggi dialami oleh remaja.

Tobias dan Weissbrod (1980) menyatakan kecemasan matematika adalah rasa panik, tidak berdaya, kekakuan, lumpuh, dan gangguan mental yang muncul dalam diri seseorang ketika mereka diminta untuk menyelesaikan suatu permasalahan matematika. Richardson dan Suinn (dalam Satriyani, 2016) berpendapat kecemasan matematika adalah reaksi kaku dan bimbang yang menghambat proses manipulasi angka dan pemecahan permasalahan matematika secara menyeluruh dalam aktivitas sehari-hari atau dalam situasi akademik. Whyte (dalam Whyte dan Anthony, 2012) mendefinisikan kecemasan matematika sebagai suatu rasa takut, atau fobia yang menghasilkan respons negatif terhadap proses belajar, atau melakukan aktifitas matematika.

Kecemasan matematika dapat menghasilkan efek negatif kepada kemampuan belajar, kemampuan menerapkan, dan kemampuan memecahkan masalah. Whyte dan Anthony (2012) berpendapat kecemasan matematika mampu memengaruhi seseorang melalui aspek kognitif, afektif, atau fisik. Salah satu contoh reaksi kognitif yaitu siswa beranggapan bahwa dia kurang mampu menyelesaikan suatu masalah matematika, pikiran menjadi kosong pada saat menyelesaikan suatu masalah matematika, dan menghindari pelajaran matematika secara menyeluruh. Contoh reaksi afektif yaitu tidak percaya diri, ketakutan dilihat teman sebagai siswa yang bodoh. Contoh reaksi fisik yaitu meningkatnya detak jantung, kekakuan, dan kepala pusing.

Young, C. B, dkk (2012) melalui riset di bidang neurocognitive menarik kesimpulan bahwa kecemasan matematika dapat menghambat proses berpikir seseorang dalam mencari solusi dari suatu permasalahan matematika. Untuk mencari penyelesaian dari suatu masalah matematika, daya ingat sangat diperlukan. Kecemasan matematika dapat menghambat daya ingat karena otak akan terlalu sibuk mengkhawatirkan tentang matematika dibanding mencari solusi akan permasalahan matematika yang dihadapi. Hal ini menunjukkan bahwa ketika seseorang mengalami kecemasan matematika, ia akan mengalami hambatan dalam memahami konsep matematika yang sedang diajarkan atau ia akan mengalami hambatan dalam menggunakan konsep matematika yang telah mereka miliki untuk menjawab suatu pertanyaan.

Terdapat berbagai metode yang dapat digunakan dalam mengukur kecemasan siswa. Salah satunya yaitu dengan menggunakan The Mathematics Anxiety Rating Scale (MARS). MARS di kembangkan oleh Richardson dan Suinn pada tahun 1972. MARS berisi 98 hal yang mendeskripsikan situasi yang menyebabkan munculnya kecemasan matematika.

Mahmood dan Khatoon pada tahun 2011 mengembangkan Mathematics Anxiety Scale dengan tujuan untuk mengembangkan alat ukur kecemasan matematika secara teoritis dan metodologis terutama dalam total korelasi, konsistensi internal, reliabilitas dan validitas. Bentuk akhir dari pengembangan tes Mahmood dan Khatoon adalah sebuah tes yang berisi 14 pernyataan yang di desain untuk mengukur kecemasan matematika siswa SMP dan SMA. Hasil pengembangan dari MARS merupakan instrumen yang lebih pendek dimana terdapat 7 pernyataan yang positif dan 7 pernyataan yang negatif, 
menggunakan skala likert 5 poin dengan tujuan mengukur dimensi positif dan negatif dari kecemasan matematika siswa

Berdasarkan observasi dan percakapan singkat peneliti pada program PLP. Beberapa siswa di SMPN 13 surabaya beranggapan bahwa matematika adalah salah satu mata pelajaran yang paling menakutkan, dan rasa takut tersebut menyebabkan kecemasan terhadap mata pelajaran matematika pada siswa dalam proses pembelajaran. Siswa merasa cemas ketika diminta mengerjakan soal didepan, khawatir jawabannya akan salah karena takut dilihat siswa lain sebagai siswa yang bodoh, kurangnya percaya diri dalam menjawab soal, dan terdapat berbagai contoh kecemasan matematika yang lain.

Bruner (1961) mendeskripsikan masalah sebagai situasi yang membuat seseorang marah dan merasa tidak nyaman. Menurut Kantowski (1977) seorang individu dianggap menghadapi permasalahan pada saat dia bertemu dengan pertanyaan yang tidak bisa dia jawab, atau situasi yang tidak bisa dia selesaikan menggunakan pengetahuan yang dia miliki. Dia harus berpikir sebuah jalan dengan informasi yang dia miliki supaya mencapai tujuan yang diinginkan dari masalah tersebut. Buchanan (1987) mendeskripsikan masalah matematika sebagai suatu masalah non-rutin yang memerlukan lebih dari prosedur dasar atau algoritma dalam proses solusinya. Gagne berpendapat (dalam Mulyasa, 2008) bahwa siswa yang berhadapan dengan suatu permasalahan tidak hanya semata-mata memecahkan masalah, tetapi mereka juga mempelajari suatu hal yang baru. Polya (1973) menyatakan bahwa pemecahan masalah adalah kegiatan yang dilakukan dengan cara mengubah pandangan seseorang terhadap suatu masalah dengan tujuan mengidentifikasi masalah dan menentukan cara untuk menyelesaikan masalah tersebut. Solusi dari suatu permasalahan tidak hanya berupa jawaban, melainkan juga memuat prosedur-prosedur yang harus dilakukan dalam memperoleh jawaban tersebut. Sehingga, dalam memecahkan masalah, siswa harus menggunakan langkah-langkah yang didasari alasan yang kuat dan penyelesaian yang detail.

Di dalam dunia pendidikan, terdapat suatu metode pembelajaran yang disebut pembelajaran berbasis masalah. Siswa diminta untuk melakukan berbagai aktivitas dimana dia akan menggunakan pengetahuan dan pengalaman dalam kehidupannya dengan tujuan untuk menyelesaikan suatu permasalahan. Penggunaan permasalahan yang tidak umum, dapat mendorong perkembangan kemampuan berpikir kritis, kreatif dan higher order thinking skills dari siswa tersebut.

Salah satu strategi dalam pemecahan masalah matematika yaitu menggunakan strategi pemecahan masalah George Polya. Polya (1973) berpendapat bahwa terdapat 4 langkah dalam memecahkan suatu permasalahan, yaitu: (1) Memahami masalah dimana siswa berusaha untuk memahami masalah. (2) Membuat rencana dimana siswa akan membuat rencana dalam menyelesaikan masalah. Polya menyatakan terdapat banyak strategi dalam menyelesaikan masalah. Beberapa contohnya yaitu: bekerja mundur, menemukan pola, mengadopsi pandangan yang berbeda, menyelesaikan masalah lebih sederhana yang analog, mempertimbangkan kasus ekstrim, membuat representasi visual, menebak dan menguji, menentukan semua kemungkinan, mengorganisasikan data, penalaran logis, dan lain-lainnya. (3) Menjalankan rencana dimana siswa akan menjalankan rencana yang telah dibuat. Langkah ini cenderung lebih mudah dari langkah sebelumnya dan hal yang paling penting dalam langkah ini yaitu kesabaran. (4) Merefleksi dimana siswa setelah menyelesaikan masalah tersebut siswa akan melihat kembali, apakah ada bagian dari rencana yang bekerja atau ada bagian dari rencana yang gagal untuk dijalankan. Melalui langkah ini, Siswa dapan menentukan bagaimana cara yang efektif dalam menyelesaikan masalah-masalah yang akan muncul di masa depan.

Melalui berbagai metode dan strategi pemecahan masalah yang ada, siswa seharusnya dapat menyelesaikan suatu permasalahan. Akan tetapi, berdasarkan observasi peneliti kenyataan di sekolah terdapat siswa yang kurang mampu menyelesaikan permasalahan yang diberikan oleh guru. Siswa memiliki kendala di fase-fase tertentu. Kesalahan yang dilakukan siswa tersebut terkadang bersifat sepele. Misalnya kesalahan dalam membaca soal, kesalahan dalam memahami soal, kurangnya pemahaman tentang materi, kesalahan kalkulasi, dan kesalahankesalahan lainnya.

Kastolan (1992) mengkategorikan kesalahan menjadi 3 jenis, yaitu:

1) Kesalahan prosedural dengan indikator:

a)P enggunaan rumus, teorema, atau definisi yang kurang tepat.

b) Penggunaan rumus, teorema, atau definisi yang kurang cocok dengan konteks, dan syarat berfungsinya rumus, teorema, atau definisi tersebut.

c) Tidak menuliskan rumus, teorema, atau definisi yang digunakan dalam mencari solusi dari permasalahan tersebut.

2) Kesalahan konseptual dengan indikator:

a) Penggunaan langkah yang kurang sistematis.

b) Kurang mampu dalam menerapkan rumus pada langkah untuk mencari solusi dari masalah tersebut.

3) Kesalahan Teknikal dengan indikator adanya kesalahan proses menghitung dengan indikator kesalahan dalam operasi hitung. 
Sudah menjadi tugas dari guru untuk membantu siswa menangani kesalahan yang dilakukan siswa tersebut pada proses penyelesaian suatu masalah matematika supaya kesalahan yang sama tidak akan terulang pada jenjang pendidikan selanjutnya.

Berdasarkan latar belakang diatas, peneliti tertarik untuk melakukan penelitian dengan judul "Analisis Kesalahan Siswa Dalam Menyelesaikan Permasalahan Matematika Menurut Teori Polya Ditinjau dari Kecemasan Matematika". Tujuan dari penelitian ini adalah mendeskripsikan mengenai jenis-jenis kesalahan yang dilakukan oleh siswa kelas VII SMP dalam menyelesaikan suatu permasalahan dengan materi phytagoras berdasarkan teori Polya dengan tingkat kecemasan matematika tinggi dan rendah.

\section{METODE}

Penelitian ini termasuk penelitian deskriptif dengan mempergunakan pendekatan kualitatif. Dalam penelitian ini, data yang akan dideskripsikan yaitu data kualitatif mengenai analisis kesalahan siswa dalam memecahkan masalah matematika berdasarkan teori Polya ditinjau berdasarkan kecemasan matematika siswa.

Sumber data pada penelitian ini yaitu 5 siswa SMP di lingkungan peneliti pada Kelurahan Sidosermo, Kecamatan Woncolo, Kota Surabaya yang telah memperoleh materi phytagoras. Selanjutnya akan dipilih 1 subjek pada tiap tingkatan kecemasan matematika dengan memilliki kriteria yaitu melakukan kesalahan dalam proses pemecahan masalah, dan dapat mengkomunikasikan proses berpikirnya secara lancar dan terbuka.

Instrumen yang digunakan dalam penelitian yaitu sebagai berikut:

1. Instrumen Utama

Peneliti sendiri merupakan instrumen utama dalam penelitian ini. Karena dalam penelitian ini, peneliti bertugas secara langsung untuk memilih fokus penelitian, menyusun instrumen penelitian, memilih subjek penelitian, mengumpulkan data, mereduksi data, menganalisis data, menafsirkan data, menyajikan data, dan menyusun kesimpulan.

2. Angket kecemasan matematika siswa

Lembar angket diberikan kepada seluruh siswa yang merupakan anggota dari calon subjek. Angket ini digunakan untuk menentukan apakah siswa terletak dalam kelompok kecemasan matematika tinggi atau kelompok kecemasan matematika rendah. Angket yang digunakan dalam penelitian ini yaitu angket yang diadaptasi dari angket Mathematics Anxiety Scale yang dikembangkan oleh Mahmood dan Khatoon (2011).

3. Tes pemecahan masalah matematika
Tes pemecahan masalah matematika diberikan kepada seluruh siswa yang merupakan anggota dari calon subjek. Tes ini digunakan untuk mengetahui letak kesalahan-kesalahan siswa dalam proses pemecahan masalah. Tes ini terdiri dari 1 butir soal berbentuk uraian yang dikerjakan dalam waktu 30 menit.

4. Pedoman wawancara

Pedoman wawancara berisi butir-butir pertanyaan yang dapat digunakan untuk memperoleh, menggali, dan memperjelas informasi mengenai faktor-faktor penyebab subjek melakukan kesalahan dalam proses pemecahan masalah. Wawancara akan dilakukan terhadap siswa yang dipilih sebagai subjek.

Untuk menganalisis data yang diperoleh, peneliti menggunakan indikator-indikator sebagai berikut.

Tabel 1 Indikator Kesalahan siswa dalam proses pemeahan masalah berdasarkan langkah pemeahan masalah Polya

\begin{tabular}{|c|c|}
\hline $\begin{array}{c}\text { Tahap Pemecahan } \\
\text { Masalah Polya }\end{array}$ & Indikator \\
\hline $\begin{array}{l}\text { Memahami } \\
\text { Masalah }\end{array}$ & $\begin{array}{l}\text { Subjek mampu memahami } \\
\text { informasi yang diketahui dan } \\
\text { ditanyakan. }\end{array}$ \\
\hline Membuat Rencana & $\begin{array}{l}\text { Subjek mampu memilih dan } \\
\text { menjelaskan informasi, rumus, } \\
\text { atau teorema yang akan digunakan } \\
\text { untuk menyelesaikan masalah. }\end{array}$ \\
\hline \multirow{2}{*}{$\begin{array}{l}\text { Menjalankan } \\
\text { Rencana }\end{array}$} & $\begin{array}{l}\text { Subjek mampu melaksanakan } \\
\text { rencana penyelesaian masalah } \\
\text { yang telah dibuat. }\end{array}$ \\
\hline & $\begin{array}{l}\text { Subjek mampu melaksanakan } \\
\text { operasi hitung yang digunakan } \\
\text { dalam proses pemecahan masalah } \\
\text { secara tepat. }\end{array}$ \\
\hline \multirow[b]{2}{*}{$\begin{array}{l}\text { Memeriksa } \\
\text { Kembali }\end{array}$} & $\begin{array}{l}\text { Subjek memeriksa kembali } \\
\text { jawaban dari pemecahan masalah. }\end{array}$ \\
\hline & $\begin{array}{l}\text { Subjek merefleksi kembali dan } \\
\text { menyusun kesimpulan tentang } \\
\text { permasalahan yang diberikan. }\end{array}$ \\
\hline
\end{tabular}

\section{HASIL DAN PEMBAHASAN}

Berdasarkan analisis data yang telah dilakukan peneliti, diperoleh hasil dan pembahasan mengenai analisis kesalahan siswa dalam menyelesaikan permasalahan matematika menurut teori Polya ditinjau dari kecemasan matematika sebagai berikut

1. Analisis Kesalahan Siswa Dalam Menyelesaikan Permasalahan Matematika Menurut Teori Polya Ditinjau dari Kecemasan Matematika Tinggi. 


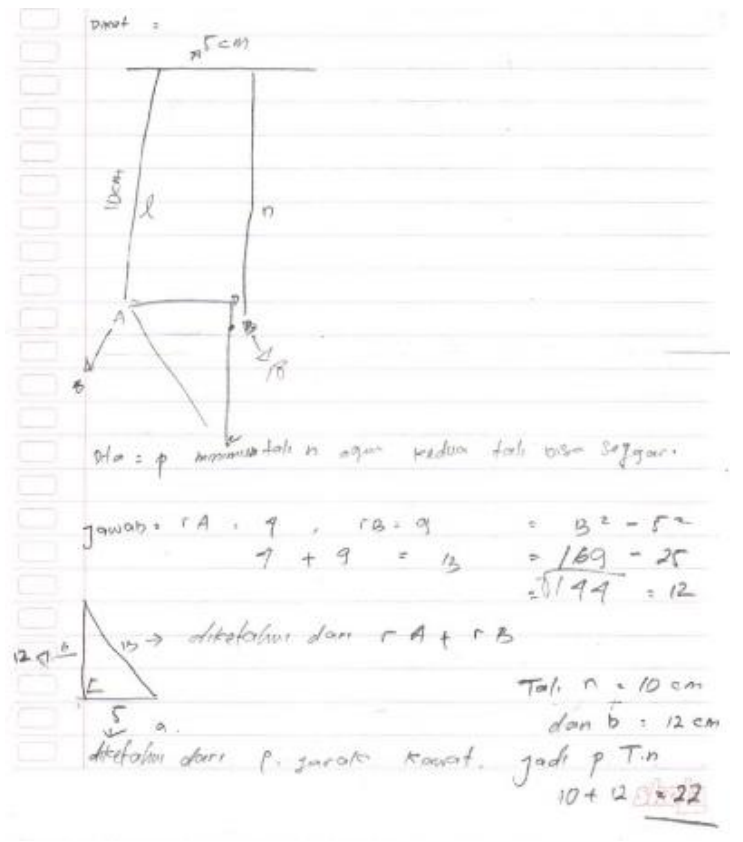

Gambar 1 Lembar Jawaban subjek Dengan Tingkat Kecemasan Tinggi

Cuplikan dari wawancara berikut menjelaskan proses berpikir subjek dalam fase memahami masalah.

Peneliti: Apakah kamu tahu informasi-informasi yang diketahui dalam soal ini? Coba jelaskan apa saja!

Subjek: Diketahui diameter bola A dan bola B. Diameter bola A yaitu $8 \mathrm{~cm}$ sementara bola B $18 \mathrm{~cm}$. tali L $10 \mathrm{~cm}$ jarak antar tali $5 \mathrm{~cm}$

Peneliti: Setelah yang diketahui, apakah kamu tahu apa yang ditanyakan?

Subjek: Yang ditanyakan, panjang tali $\mathrm{n}$ agar bolanya tidak berimpitan dan talinya harus sejajar.

Peneliti: Kamu kan sudah memahami apa yang diketahui dan ditanyakan dalam soal ini, tetapi kenapa tidak ditulis dalam lembar jawaban?

Subjek: Kebiasaan, kan lumayan bisa menghemat waktu

Dalam lembar jawaban, subjek tidak menuliskan informasi-informasi yang diketahui dalam soal, akan tetapi berdasarkan hasil wawancara yang dilakukan, subjek dapat menjelaskan secara tepat informasiinformasi yang diketahui dan ditanyakan dalam permasalahan yang diujikan. Subjek merasa sudah terbiasa untuk tidak menulis informasi yang diketahui dengan tujuan menghemat waktu. Hal ini sesuai dengan temuan Widodo (2013) yang menyatakan bahwa siswa yang melakukan kesalahan pada suatu tahap masalah dan dapat menyelesaikan masalah pada tahap berikutnya, mereka belum dapat dikategorikan melakukan kesalahan konsep. Dari hasil wawancara yang dilakukan Widodo, dapat ditarik kesimpulan siswa tidak menulis apa yang diketahui dan apa yang ditanya dengan alasan untuk menghemat waktu. Temuan yang sama juga ditemukan oleh Kristofora (2017). Dari wawancara yang dilakukan Kristofora, dapat ditarik kesimpulan siswa tidak menulis apa yang diketahui dan apa yang ditanya dengan alasan sudah terbiasa mengerjakan soal tanpa menuliskan apa yang diketahui.

Dapat ditarik kesimpulan bahwa dalam tahap memahami masalah, subjek dengan tingkat kecemasan tinggi telah memenuhi indikator mampu memahami informasi-informasi yang diketahui dan ditanyakan dalam permasalahan yang diujikan.

Cuplikan dari wawancara berikut menjelaskan proses berpikir siswa dalam fase membuat rencana.

Peneliti: Langkah-langkah apa yang kamu lakukan untuk menyelesaikan soal? Coba jelaskan!

Subjek: Saya coba-coba menggambar hasilnya nanti bola dan talinya gimana. Terus saya hitung jarak A dan B

Peneliti: Setelah itu?

Subjek: $\quad$ Saya bikin segitiga A, B dan ini. Terus dengan rumus phytagoras bisa dihitung panjang B kesini. Terus tinggal dijumlahkan

Peneliti: Apa yang dijumlahkan?

Subjek: Panjang tali L, dan hasil phytagoras

Berdasarkan lembar jawaban, subjek kurang mampu mengilustrasikan solusi dari permasalahan yang diberikan. Hal ini dapat diketahui dari ilustrasi solusi dari permasalahan yang memiliki beberapa kesalahan.

Berdasarkan hasil wawancara yang dilakukan, subjek telah mampu untuk menggunakan teorema phytagoras dalam menentukan panjang dari salah satu komponen tali, akan tetapi rencana yang telah dibuat subjek memiliki kesalahan dalam menghitung panjang total tali. Hal ini berkaitan dengan ilustrasi yang telah dibuat subjek.

Subjek melakukan kesalahan dalam kategori kesalahan prosedural. Subjek memenuhi indikator penggunaan rumus, teorema, atau definisi yang kurang tepat karena rumus yang disusun oleh subjek untuk menentukan panjang total tali memiliki kesalahan.

Dapat ditarik kesimpulan bahwa dalam tahap membuat rencana, subjek dengan tingkat kecemasan tinggi tidak memenuhi indikator mampu memilih dan 
menjelaskan informasi, rumus, atau teorema yang akan digunakan untuk menyelesaikan masalah.

Cuplikan dari wawancara berikut menjelaskan proses berpikir subjek dalam fase menjalankan rencana.

Peneliti: Coba jelaskan bagaimana proses yang kamu lakukan untuk menyelesaikan soal sesuai dengan rencana yang telah kamu buat?

Subjek: Awalnya, saya hitung jarak antara A dan $B$, lalu dengan rumus phytagoras saya hitung panjang tali, setelah itu saya jumlahkan dengan panjang tali $\mathrm{L}$

Peneliti: Apakah kamu merasa kesulitan dalam melakukan operasi-operasi yang diperlukan untuk memecahkan masalah?

Subjek: Tidak

Berdasarkan hasil wawancara yang dilakukan, subjek telah menjalankan rencana yang telah dibuat secara benar dan mampu melaksanakan operasi hitung secara benar. Akan tetapi, rencana yang dibuat subjek memiliki kesalahan dan subjek kurang teliti dalam menghitung panjang total tali. Hal ini dapat diketahui dari lembar jawaban subjek dimana subjek menghitung panjang total tali dengan cara menjumlahkan panjang tali L dan jarak titik B ke titik yang dikonstruksi subjek.

Dapat ditarik kesimpulan bahwa dalam tahap menjalankan rencana, subjek dengan tingkat kecemasan tinggi tidak memenuhi indikator mampu menjalankan rencana yang telah dibuat dan mampu melaksanakan operasi hitung yang digunakan dalam proses pemecahan masalah secara tepat

Cuplikan dari wawancara berikut menjelaskan proses berpikir subjek dalam fase memeriksa kembali.

Peneliti: Apakah kamu sudah yakin dengan solusi yang kamu berikan?

Subjek: Ya

Peneliti: Apakah solusi yang kamu berikan sudah diperiksa kembali?

Subjek: Sudah, hitungannya sudah saya cek dan sudah benar

Peneliti: Apakah menurutmu rencana yang telah kamu buat sudah efektif?

Subjek: Kayaknya iya

Berdasarkan hasil wawancara yang dilakukan, subjek telah memeriksa kembali dan merasa percaya diri dengan jawaban yang dia berikan. Hal ini menunjukkan bahwa subjek cenderung tergesa-gesa dalam memeriksa kembali jawaban yang telah diperoleh, karena jika subjek dapat memeriksa kembali jawabannya secara benar, seharusnya subjek dapat menarik kesimpulan bahwa dia melakukan kesalahan dalam menghitung panjang total tali.

Dapat ditarik kesimpulan bahwa dalam tahap memeriksa kembali, subjek dengan tingkat kecemasan tinggi tidak memenuhi indikator memeriksa kembali jawaban dari pemecahan masalah, merefleksi kembali dan menyusun kesimpulan tentang permasalahan yang diberikan.

2. Analisis Kesalahan Siswa Dalam Menyelesaikan Permasalahan Matematika Menurut Teori Polya Ditinjau dari Kecemasan Matematika Rendah.

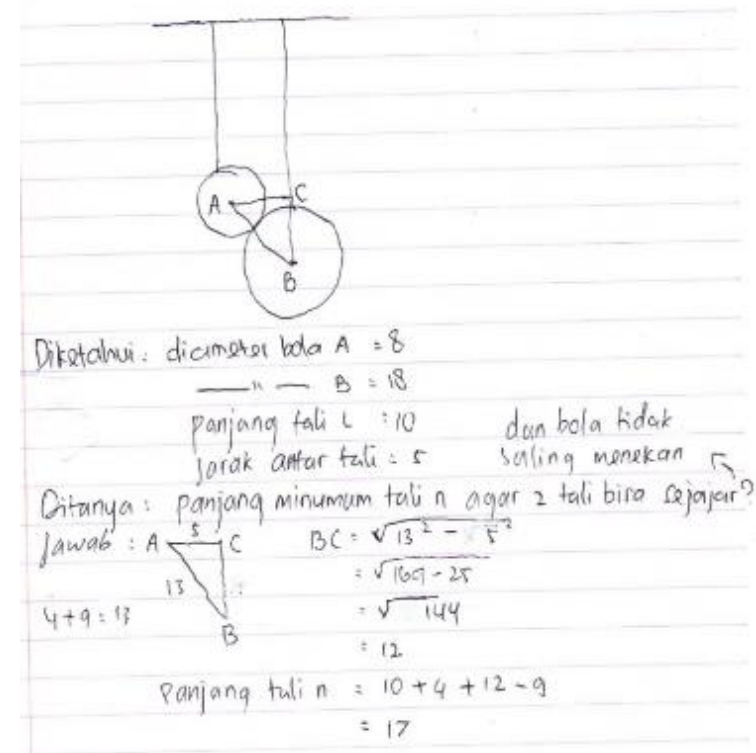

Gambar 2Lembar Jawaban Subjek Dengan Tingkat Kecemasan Rendah

Cuplikan dari wawancara berikut menjelaskan proses berpikir subjek dalam fase memahami masalah.

Peneliti: Apakah kamu tahu informasi-informasi yang diketahui dalam soal ini? Coba jelaskan apa saja!

Subjek: Iya, diameter bola A 8 dan bola B 18 , panjang tali L 10, jarak antar tali 5

Peneliti: Apakah kamu tahu pertanyaan yang diajukan dalam soal? Coba jelaskan!

Subjek: Panjang minimum tali $\mathrm{n}$ agar kedua tali sejajar dan bola tidak saling menekan.

Subjek telah menuliskan secara terperinci informasi-informasi yang diketahui dan ditanyakan secara rapi dalam lembar jawaban. Berdasarkan hasil wawancara yang dilakukan, subjek telah mampu menjelaskan informasi-informasi yang diketahui dan ditanyakan dalam permasalahan yang diujikan.

Dapat ditarik kesimpulan bahwa dalam tahap memahami masalah, subjek dengan tingkat kecemasan rendah telah memenuhi indikator mampu memahami informasi-informasi yang diketahui dan ditanyakan dalam permasalahan yang diujikan. 
Cuplikan dari wawancara berikut menjelaskan proses berpikir subjek dalam fase membuat rencana.

Peneliti: Langkah-langkah apa yang kamu lakukan untuk menyelesaikan soal? Coba jelaskan!

Subjek: Pertama, saya menggambar ilustrasi dari jawaban, setelah itu saya mengukur panjang $\mathrm{AB}$ dan membuat segitiga $\mathrm{ABC}$. Selanjutnya, saya menghitung panjang BC menggunakan phytagoras. Selanjutnya, saya menghitung panjang total tali N

Peneliti: Setelah itu?

Subjek: $\quad$ Saya bikin segitiga A, B dan ini. Terus

Berdasarkan lembar jawaban, subjek telah mampu mengilustrasikan solusi dari permasalahan yang diberikan. Berdasarkan hasil wawancara yang dilakukan, subjek telah memahami dalam menentukan panjang dari salah satu komponen tali dapat menggunakan teorema phytagoras, dan memahami untuk menghitung panjang total tali secara benar dengan cara: Panjang L + Jari-Jari Bola A + Jarak Titik B ke Titik C - Jari-Jari Bola B.

Dapat ditarik kesimpulan bahwa dalam tahap membuat rencana, subjek dengan tingkat kecemasan rendah telah memenuhi indikator mampu memilih dan menjelaskan informasi, rumus, atau teorema yang akan digunakan untuk menyelesaikan masalah.

Cuplikan dari wawancara berikut menjelaskan proses berpikir subjek dalam fase menjalankan rencana.

Peneliti: Jelaskan bagaimana proses yang kamu lakukan untuk menyelesaikan soal sesuai dengan rencana yang telah kamu buat?

Subjek: Pertama, saya menggambar ilustrasi dari jawaban, setelah itu saya menghitung panjang AB dengan cara menambah jarijari bola A dan B. Selanjutnya, saya membuat segitiga $\mathrm{ABC}$ dan menghitung panjang BC dengan phytagoras.. Setelah itu hitung panjang tali $\mathrm{N}$.

Peneliti: Apakah kamu merasa kesulitan dalam melakukan operasi-operasi yang diperlukan untuk memecahkan masalah? Subjek: Tidak

Subjek telah menuliskan secara rapi, dan terperinci penyelesaian dari masalah yang diujikan. Subjek telah mampu melaksanakan operasi hitung secara benar. Berdasarkan hasil wawancara yang dilakukan, subjek telah menjalankan rencana yang telah dibuat secara benar dan berurutan. Subjek tidak merasa kesulitan ketika melaksanakan operasi hitung.
Dapat ditarik kesimpulan bahwa dalam tahap menjalankan rencana, subjek dengan tingkat kecemasan rendah telah memenuhi indikator mampu menjalankan rencana yang telah dibuat dan mampu melaksanakan operasi hitung yang digunakan dalam proses pemecahan masalah secara tepat.

Cuplikan dari wawancara berikut menjelaskan proses berpikir subjek dalam fase memeriksa kembali.

Peneliti: Apakah kamu sudah yakin dengan solusi yang kamu berikan?

Subjek: Ya, saya yakin

Peneliti: Apakah solusi yang kamu berikan sudah diperiksa kembali?

Subjek: Belum, waktunya tinggal sedikit

Peneliti: Apakah menurutmu rencana yang telah kamu buat sudah efektif?

Subjek: Mungkin sih

Berdasarkan hasil wawancara yang dilakukan, subjek merasa percaya diri dengan jawaban yang dia berikan. Akan tetapi, subjek tidak memeriksa kembali dan. Hal ini terjadi karena waktu yang diberikan telah habis.

Subjek melakukan kesalahan dalam kategori kesalahan konseptual. Subjek memenuhi indikator penggunaan langkah-langkah yang tidak sistematis karena subjek menghabiskan banyak waktu dalam mengilustrasikan solusi dari permasalahan yang diberikan sehingga subjek kehabisan waktu dalam tahap memeriksa kembali.

Dapat ditarik kesimpulan bahwa dalam tahap memeriksa kembali, subjek dengan tingkat kecemasan rendah tidak memenuhi indikator memeriksa kembali jawaban dari pemecahan masalah, merefleksi kembali dan menyusun kesimpulan tentang permasalahan yang diberikan

\section{PENUTUP}

\section{Simpulan}

Berdasarkan hasil analisis data, peneliti menarik kesimpulan sebagai berikut

1. Siswa SMP Kelas VIII tingkat kecemasan matematika tinggi kurang mampu dalam menyelesaikan permasalahan matematika. Siswa telah mampu memahami masalah, siswa mampu menjelaskan informasi-informasi yang diketahui dan yang ditanyakan. Pada tahap membuat rencana, siswa kesulitan dalam memilih dan menentukan informasi-informasi, rumus, dan teorema yang akan digunakan dalam mencari solusi dari masalah. Hal tersebut mengakibatkan siswa mengalami kesalahan dalam tahap selanjutnya yaitu tahap menjalankan rencana dan 
memeriksa kembali. Dalam tahap menjalankan rencana, siswa tidak kesulitan dalam proses operasi hitung. Dalam tahap memeriksa kembali, siswa sudah berusaha untuk memeriksa apakah solusi yang dia peroleh sudah benar atau masih salah. Akan tetapi siswa tidak menyadari letak kesalahan yang dialami oleh siswa. Siswa beranggapan bahwa solusi yang diperoleh sudah benar.

Subjek melakukan kesalahan kategori kesalahan prosedural. Subjek memenuhi indikator penggunaan rumus, teorema, atau definisi yang kurang tepat karena rumus yang disusun oleh siswa untuk menentukan panjang total tali memiliki kesalahan.

2. Siswa SMP Kelas VIII tingkat kecemasan matematika rendah telah mampu dalam menyelesaikan permasalahan matematika. Siswa telah mampu memahami masalah, siswa mampu menjelaskan informasi- informasi yang diketahui dan yang ditanyakan. Dalam tahap membuat rencana, siswa telah mampu menyusun rencana pemecahan masalah yang benar. Siswa dapat memilih dan menentukan informasi-informasi, rumus, dan teorema yang akan digunakan dalam mencari solusi dari masalah. Dalam tahap menjalankan rencana, siswa telah mampu menjalankan rencana yang telah dia buat secara sistematis dan tidak kesulitan dalam proses operasi hitung. Dalam tahap memeriksa kembali, siswa mengalami kesalahan karena alokasi waktu sudah habis dan siswa belum selesai memeriksa apakah solusi yang diperoleh sudah tepat atau masih terdapat kesalahan. Siswa beranggapan bahwa solusi yang diperoleh sudah benar.

Subjek melakukan kesalahan kategori kesalahan konseptual. Subjek memenuhi indikator penggunaan langkah-langkah yang tidak sistematis karena subjek menghabiskan banyak waktu dalam mengilustrasikan solusi dari masalah yang dihadapi sehingga subjek kehabisan waktu dalam tahap memeriksa kembali.

\section{Saran}

Berdasarkan penelitian yang telah dilakukan, peneliti memberi saran sebagai berikut.

1. Hasil penelitian mengindikasikan siswa dengan tingkat kecemasan matematika tinggi kurang mampu dalam menyelesaikan masalah matematika. Guru diharapkan mampu melatih siswa untuk memecahkan masalah matematika melalui soal-soal berbasis masalah terutama dalam tahap membuat rencana supaya siswa terbiasa untuk menyelesaikan masalah matematika. Hal tersebut dapat dilakukan dengan penggunaan soal berbasis masalah dalam pembelajaran sehari-hari.

2. Hasil penelitian mengindikasikan siswa dengan tingkat kecemasan matematika tinggi melakukan kesalahan kategori kesalahan konseptual dan siswa dengan tingkat kecemasan matematika rendah melakukan kesalahan kategori kesalahan prosedural. Diharapkan penelitian selanjutnya lebih memperdalam terutama dalam faktor-faktor penyebab siswa melakukan kesalahan dan solusinya.

3. Penelitian terbatas dengan siswa dengan tingkat kecemasan matematika tinggi dan rendah. Diharapkan penelitian selanjutnya menggunakan kemampuan matematis dan kecerdasan emosional sebagai tinjauan

\section{DAFTAR PUSTAKA}

Bruner, J. 1961. The Act of Discovery. Harvard Educational Review.

Buchanan, N. 1987. Factors contributing to mathematical problem-solving performance: An exploratory study. Educational Studies in Mathematics.

Handayani, S. 2019. Pengaruh Kecemasan Matematika terhadap Pemahaman Konsep Matematika. SAP (Susunan Artikel Pendidikan)

Herman, T. 2000. Strategi Pemecahan Masalah (Problem Solving) Dalam Pembelajaran Matematika. LPM Institut Teknologi Bandung.

Hiebert, J., \& Lefevre, P. (1986). Conceptual and procedural knowledge in mathematics: An introductory analysis. Hillsdale, NJ: Lawrence Erlbaum Associates

Hudojo, H. 2005. Pengembangan Kurikulum dan Pembelajaran Matematika. Malang: UM Press.

Kantowski, M. G. 1977. Processes involved in mathematical problem solving. Journal for Research in Mathematics Education.

Kastolan, dkk.. (1992). Identifikasi Jenis-jenis Kesalahan Menyelsaikan Soal-soal Matematika yang DIlakukan Peserta DIdik Kelas 2 Program A1 SMA Negeri Se-Kotamdya Malang. Malang: IKIP Malang.

Kristofora, M., Sujadi, A. (2017). ANALISIS KESALAHAN DALAM MENYELESAIKAN MASALAH MATEMATIKA DENGAN MENGGUNAKAN LANGKAH POLYA SISWA KELAS VII SMP. Prisma.

Luttenberger, S., Wimmer, S., Paechter, M. 2018. Spotlight on Math Anxiety. Psychology Research and Behaviour Management. 
Mahmood, S., Khatoon, T., 2011. Development and Validation of the MathematicsAnxiety Scale for Secondary and Senior SecondarySchool Students. British Journal of Arts and Social Sciences. Vol. 2. No. 2

Marshall, E., Mann, V., \& Wilson, D. 2016. Maths anxiety: A collaboration. HEA STEM conference, Nottingham

Mulyasa, E. 2008. Menjadi Guru profesional: Menciptakan Pembelajaran Kreatif dan Menyenangkan. Bandung: Remaja Rosdakarya

Ortiz, E. 2016. The Problem-Solving Process in a Mathematics Classroom. Florida: Florida Association of Mathematics.

Peker, M. 2009. Pre-Service Teachers' Teaching Anxiety about Mathematics and Their Learning Styles. Article in Eurasia Journal of Mathematics, Sciences, and Technology Education.

Polya, G. 1973. How to solve it. New Jersey: Princenton University Press

Putri, Watik Aprilia. 2020. Profil Kemampuan Pemecahan Masalah Matematika Siswa SMP pada Materi Segiempat Ditinjau dari Tipe Kepribadian Ekstrovert-Introvert. Jurnal MathEdu UNESA.

Sahriah, S., Muksar, M., \& Lestari, T. E. 2012. Analisis Kesalahan Siswa dalam Menyelesaikan Soal
Matematika Materi Operasi Pecahan Bentuk Aljabar Kelas VIII SMP Negeri 2 Malang. Jurnal Pendidikan Matematika

Satriyani. 2016. Pengaruh Kecemasan Matematika (Mathematics Anxiety) dan Gender Terhadap Kemampuan Pemecahan Masalah Matematis Siswa. Universitas Islam Negeri Syarif Hidayattullah Jakarta.

Singgih D. Gunarsa. 2001. Psikologi Anak Bermasalah. Kwitang Jakarta. BPK Gunung Mulia.

Syahlan, S. 2017. Sepuluh Strategi Dalam Pemecahan Masalah Matematika.

Tobias, S., Weissbrod, C., 1980. Anxiety and mathematics: an update. Harvard Educational Review.

Widodo, S. A. 2013. Analisis Kesalahan Dalam Pemecahan Masalah Divergensi Tipe Membuktikan Pada Mahasiswa Matematika. Jurnal Pendidikan dan Pengajaran.

Whyte, J., Anthony, G. 2012. Maths Anxiety: The Fear Factor in the Mathematics Classroom. New Zealand: Journal of Teacher's Work

Young, C. B., Wu, S. S., \& Menon, V. (2012). The neurodevelopmental basis of math anxiety. Psychological Science 